
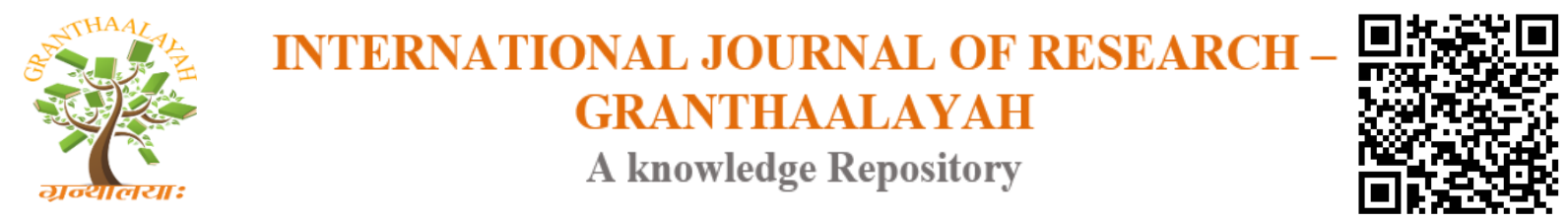

Social

\title{
THE EFFECT OF USING POWERPOINT PRESENTATIONS IN ACADEMIC ACHIEVEMENT OF SOCIAL AND NATIONAL STUDIES IN THE FIFTH GRADE STUDENTS AT-RISK FOR LEARNING DISABILITIES
}

\author{
Dr. Ibrahim Rajab Abbas Ibrahim *1 \\ ${ }^{* 1}$ Department of Special Education, Najran University, Kingdom of Saudi Arabia
}

\begin{abstract}
The purpose of this study was to identify the effect of using PowerPoint presentations in academic achievement of Social and National Studies in the fifth grade students at-risk for learning disabilities at Najran in the Kingdom of Saudi Arabia. The sample of the study consisted of (10) students at-risk for learning disabilities; it was divided randomly into two equal groups: control and experimental. The students in the experimental group have studied the first unit who it consists of five lessons in Social and National Studies by using PowerPoint presentations; however, the students in the control group were received their teaching by using traditional tool (blackboard and chalk). The Social and National Studies Academic Achievement Test: was applied for two groups as pre-test and post-test. Results revealed that the students taught Social and National Studies with PowerPoint presentations performed better than their counterparts taught with traditional tool (blackboard and chalk) in favor of the students in the experimental group.
\end{abstract}

Keywords: PowerPoint presentations; Social and National Studies; students at-risk for Learning Disability.

Cite This Article: Dr. Ibrahim Rajab Abbas Ibrahim. (2018). "THE EFFECT OF USING POWERPOINT PRESENTATIONS IN ACADEMIC ACHIEVEMENT OF SOCIAL AND NATIONAL STUDIES IN THE FIFTH GRADE STUDENTS AT-RISK FOR LEARNING DISABILITIES." International Journal of Research - Granthaalayah, 6(3), 191-202. https://doi.org/10.29121/granthaalayah.v6.i3.2018.1514.

\section{Introduction}

In recent years, technology has started to have a presence in classrooms and plays an important role in pedagogy. When teachers use it in their classrooms, in fact, they want to attract the students' attention, so that they can enhance effective ways of learning.

Technology is not a strategy in and of itself; rather, it is an adaptable and powerful tool for providing appropriate personalized learning activities and adaptations. Technology can enhance 
student independence and self-reliance with reading and writing tasks and provide valuable opportunities to practice skills specifically tailored to a student's instructional level. (Ministry of Education and British Columbia School Superintendent's Association, 2011).

Balmeo et al study (2014) indicated that the technology integration appears to be an effective method in teaching students with special needs and the lack of appropriate technology training in pre-service and in-service teacher education programs is the most cited barrier in using technology in the classroom. They further added that the lack of adequate training has an especial strong impact on students with disabilities because technology is often a critical component in planning and implementing an educational program for them.

According to Al Neyadi, study (2009) recommended the necessity of benefiting from Information technology by teachers and employing this technology in the educational process especially software production and The ministry of education should conduct training courses for Arabic teachers on using and producing instructional software.

In Parette et al, (2009), Research suggests that computers and other technologies are also useful to adapt and modify curriculum materials for students who are at risk, thus equalizing the learning opportunities for all students, so education professionals must begin to focus on how education professionals can best use them in the classroom, especially for students who are at risk and the " Kanika" study (2013) shows that PowerPoint is one of the main teaching tools that play an integral role in promoting the learning and teaching processes, thus contributing to the field of education as a whole. Application Microsoft PowerPoint provides presentations with a visual element, which can be used in the field of education to great effect.

Microsoft Power-Point is a presentation program developed by Microsoft. It is a part of the Microsoft Office system, which is widely used by business people, educators, students, and trainers. It is a complete presentation program that allows teachers to produce professionallooking presentations in classroom (Lari, 2014) provide the needs of students with learning problems. Teachers can present information using all the senses-visual, auditory, kinesthetic, and tactile - which is a highly researched and recommended approach for students with special needs. The slides should be clear, uncluttered, and easy to understand to be useful for students with special needs. (Steele, 2008)

According to Coleman, (2009).PowerPoint offers many possibilities for instruction of individuals who have disabilities. This software is widely available and easy to learn. With a little bit of time and creativity, teachers can create interesting, fun materials to reinforce learning. After slides have been created, they can be copied to multiple presentations and presentations can be saved on a disk to be used on multiple computers. Many students are motivated by computerassisted instruction and, for some students who have decreased motor, cognitive, or learning abilities, PowerPoint opens up opportunities for independent skill practice that would otherwise require adult assistance. Presentations can be sent home for additional practice for students who have PowerPoint or PowerPoint Viewer available. Teachers need only to spend a little time learning the program features and then open their imaginations to the possibilities that PowerPoint provides for creating materials to enhance instruction for their students. 
There is undoubted controversy over the application of PowerPoint to teaching. The different studies undertaken to evaluate the effects have produced mixed results. Although many said that, it improved students' performance, a few felt that it had no effect at all on their learning. (Al Othman, 2011). On the other hand, Social studies is the integrated study of the social sciences such as history, geography, economy, sociology, anthropology, psychology, philosophy, political science, law, and civic education. Many scholars point out that the disciplines of social studies are intended to develop effective citizens who possess critical thinking, problem-solving, and decision-making skills. Likewise, many researchers in the field of social studies education highlight the role of computers in engaging students in critical thinking, problem solving, and decision-making. (Aqikalin, 2010) However, few studies have investigated how social studies teachers perceive and use technology in the classroom after they obtained intensive curriculumbased technology integration training.

Side-by-side with efforts to raise the level of awareness of emerging technology applications, technology-minded social studies educators need to shift the focus of their concerns away from traditional hardware and software issues. (Martorella, 2015)

In this sense, social studies teachers should be more aware of the changes technology has brought to modem society and try to reflect this change in their own classrooms. Unfortunately, social studies curricula has not been largely affected by this technology change and technology's unique role in the enhancement of social studies education is not widely recognized. (Zhao,2007)

Boon, et al. (2007), they findings suggest several promising issues across all the social studies intervention studies reviewed. like, all the interventions confirmed that the use of technological advances in social studies instruction significantly improved and enhanced achievement for students with and without disabilities, especially for remedial students and students with LD, across age, grade levels, and content areas.

For many years, educators and policymakers looking for strategies to close the achievement gap and improve student learning have sought solutions involving new uses of technology, especially for students placed at-risk. Unfortunately, the results of technology initiatives have been mixed. Often, the introduction of technology into classrooms has failed to meet the grand expectations proponents anticipated. The educational landscape is replete with stories and studies about how at-risk students were unable to benefit from particular innovations seeking to use computers for teaching. (Hammond, 2014)

In recent years, studies have indicated conflicting findings about PowerPoint effectiveness in improving student learning (Al Neyadi, 2009; Lari, 2014). For instance, AL Ahmad, (2008) who studied the effect of PowerPoint in academic achievement in science concluded that when students were actively engaged in the class using PowerPoint presentation, academic achievement increased. Another similar study conducted by Alhabad, (2008) indicated that Increase in the fourth year primary students' achievement and positive attitudes towards using the PowerPoint Presentation in teaching. However, Szabo and Hastings (2000) found little effects of PowerPoint on students' academic achievement. Another study by Al Othman, (2011) showed that the students' performance was not increased in the basic PowerPoint presentation compared to a traditional method. In addition, Kanika, (2013) studied the effectiveness of PowerPoint 
presentation discovers student's and Lecturer's experience of technology integration within the educational setting. There was no significance differences were found regarding with student's academic performance between students from Information Technology major and English language major students.

In the study described the use of PowerPoint presentations have been investigated in Saudi Arabian Primary boys' school. Thus, this study may provide valuable views and ideas for social studies teachers and educators about the use of PowerPoint presentations -supported instruction and may inspire them to apply this sort of instruction in their classrooms with at-risk students' of learning disabilities. In this sense, the problem of the study arises in the following question:

What is the effect of PowerPoint presentations in academic achievement of Social and National Studies among at-risk students' of learning disabilities in the Kingdom of Saudi Arabia.?

\section{Null Hypothesis}

The hypotheses that were tested at 0.05 level of significance are:

1) There are no statistically significant differences between the mean rank of experimental and control groups on the pre- The Social and National Studies Academic Achievement Test.

2) There are no statistically significant differences between the mean rank of experimental and control groups on the post- The Social and National Studies Academic Achievement Test.

\section{Materials and Methods}

\section{- Research Design}

This study was based on the quasi-experimental method to test the effect of PowerPoint presentations (independent variable) in academic achievement of Social and National Studies (dependent variable) among students at-risk for learning disabilities in Najran primary Schools, Saudi Arabia.

\section{- Participants}

The participants of this study were selected from primary schools in Najran, Saudi Arabia. Ten students' at-risk for learning disabilities from fifth year students were the participants of this study. They were all boys aged 9-12. The participants were divided randomly into two equal groups control $(n=5)$ and experimental $(n=5)$. The experimental group using PowerPoint presentations in teaching Social and National Studies, while the control group was taught using traditional tool (blackboard and chalk).

\section{- Instruments}

This study included the following instruments:

1) The Social and National Studies Academic Achievement Test: In order to develop the test, the researcher reviewed the previous studies (Alhabad, 2008; Hyaty, 2007; Jerome, $\&$ Prabetta, 2005). The first draft of the test contained of (30) questions were objective type with multiple choices, which divided into three domains according to "Anderson and 
Krathwohl" (2001) for revised levels of Bloom's taxonomy of the cognitive domain in (Huitt, 2011) in terms of one of its parts, Remembering, Understanding and Applying. However, the test was reviewed by (7) experts in the field of special education, curriculum and instruction, and psychology from Najran University, and (2) teachers of Social and National Studies in Najran primary schools. However, the final draft of the test consists of (24) multiple-choice test items with four options. These items were divided equally on three domains of revised levels of Bloom's taxonomy of the cognitive domain in terms of one of its parts, Remembering, Understanding and Applying. Thus, each correct answer takes (1) mark, and (0) mark to the wrong answer. In order to identify the reliability of the test; the researcher was applied the test on a pilot study that consisted of (16) students at-risk for learning disabilities. The reliability coefficient of the test was (0.89) by using Kuder-Richardson Formula (KR-20).

2) The PowerPoint presentations with the social and national studies lessons: (see, Appendix)

PowerPoint is one of Microsoft's most used software packages. It is a representation of information that allows one to communicate the information effectively to the audience. It also allows one to show the information through various colored text, graphics, sounds, videos and animations.

The PowerPoint presentations with the social and national studies lessons were presented using laptop and smart board. The teacher presents information and displays slides of the contents to the students about each of the five lessons in the first unit of social and national studies, The PowerPoint presentations consisted of (17) sessions related to social and national studies in grade fifth in three domains of revised levels of Bloom's taxonomy of the cognitive domain. In order to ensure the validity of the guide, the researcher presented the PowerPoint presentations to the same reviewers who reviewed The Social and National Studies Academic Achievement Test. The final draft of the PowerPoint presentations on each of the five lessons in the first unit of social and national studies, consisted of (17) sessions, for (6) week, (3) sessions in per week, duration of each session was (45) minutes every day.

\section{Procedures}

This study follows these procedures:

- The sample of study consisted of (10) students at-risk for learning disabilities from the primary schools.

- The sample were divided randomly into two equal groups, control ( $\mathrm{n}=5)$ and experimental $(n=5)$.

- The students in the experimental group have studied the Social and National Studies by using PowerPoint presentations; however, the students in the control group have studied the Social and National Studies by using traditional tool (blackboard and chalk).

- The Social and National Studies Academic Achievement Test was developed and applied for the two groups as pretest and posttest.

- The test was designed to be applied collectively. The Social and National Studies Academic Achievement Test consisted of (24) item divided equally on three domains of revised levels of Bloom's taxonomy of the cognitive domain. 
- The PowerPoint presentations with the social and national studies lessons was developed which consisted of (17) sessions related to Social and National Studies in terms of one of its parts, Remembering, Understanding and Applying.

- The researcher trained social and national studies teacher on the application procedures of PowerPoint presentations with the social and national studies lessons on the experimental group members. The duration of training was (6) week, (3) sessions in per week. (3) days in week and (45) minutes every day.

- During the training process, Social and National Studies teacher provided with information about the PowerPoint presentations, its significance, the role of teacher and students, and the difference between PowerPoint presentations and traditional tool (blackboard and chalk) of teaching. In addition, Social and National Studies teacher has been trained on how to teach lessons by using PowerPoint presentations.

\section{Results}

Results related to the first hypothesis: "There are no statistically significant differences between the mean rank of experimental and control groups on the pre- The Social and National Studies Academic Achievement Test "? For this question Mann-Whitney test was used as shown in Table 1. :

Table 1: Mann-Whitney results according to pre- The Social and National Studies Academic

\begin{tabular}{|l|l|l|l|l|l|l|}
\hline Dimension & Group & $\mathbf{N}$ & Mean Rank & Sum of Ranks & Z & Sig. \\
\hline Remembering & Control & 5 & 5.00 & 25.00 & -.600 & .549 \\
\hline & Experimental & 5 & 6.00 & 30.00 & & \\
\hline Understanding & Control & 5 & 5.10 & 25.50 & -.516 & .606 \\
\hline & Experimental & 5 & 5.90 & 29.50 & & \\
\hline Applying & Control & 5 & 5.00 & 25.00 & -.655 & .513 \\
\hline Score Total & Experimental & 5 & 6.00 & 30.00 & & \\
\hline & Control & 5 & 4.70 & 23.50 & -.876 & .381 \\
\hline
\end{tabular}

Achievement Test of experimental and control groups on The Social and National Studies Academic Achievement Test. These results showed that the two groups are equivalence on the pretest.

Results related to the second hypothesis: "There are no statistically significant differences between the mean rank of experimental and control groups on the post- The Social and National Studies Academic Achievement Test "? For this question Mann-Whitney test was used as shown in Table 2. 
Table 2: Mann-Whitney results according to post- The Social and National Studies Academic Achievement Test

\begin{tabular}{|l|l|l|l|l|l|l|}
\hline Dimension & Group & $\mathbf{N}$ & Mean Rank & Sum of Ranks & $\mathbf{Z}$ & Sig. \\
& & & & & & \\
\hline Remembering & Control & 5 & 3.30 & 16.50 & -2.394 & .017 \\
\hline & Experimental & 5 & 7.70 & 38.50 & & \\
\hline Understanding & Control & 5 & 3.10 & 15.50 & -2.683 & .007 \\
\hline & Experimental & 5 & 7.90 & 39.50 & & \\
\hline Applying & Control & 5 & 3.40 & 17.00 & -2.425 & .015 \\
\hline & Experimental & 5 & 7.60 & 38.00 & & \\
\hline Score Total & Control & 5 & 3.00 & 15.00 & -2.739 & .006 \\
\hline & Experimental & 5 & 8.00 & 40.00 & & \\
\hline
\end{tabular}

Table 2 shows that there are statistically significant differences on the all domains of post- The Social and National Studies Academic Achievement Test due to the variable of group, in favor of students' at-risk for learning disabilities in the experimental group.

Statistical significance means that a result may not be the cause of random variations within the data. However, not every significant result refers to an effect with a high impact; it may even describe a phenomenon that is not really perceivable in everyday life. Statistical significance mainly depends on the sample size, the quality of the data and the power of the statistical procedures. In order to describe, if effects have a relevant magnitude, effect sizes are used to describe the strength of a phenomenon. (Cohen, 1988).

To investigate further the Effect Size (ES) of PowerPoint Presentations on the experimental group members after applying the post-test, the following formula $r=z / \sqrt{ } N$ (r: effect size; $z$ : $z$ value; N: Observation number), which is used to detect the statistical differences in MannWhitney's U test. It was shown by using an equation that the magnitude of the ES was (-0.87) and the level of effect was significant. Indicating that PowerPoint Presentations have a significance on enhancing the academic achievement of Social and National Studies for the fifth grade students at-risk for learning disabilities at primary schools in Najran, Saudi Arabia. Cohen (1988) confirmed that the impact size index is small with a value of 0.20 and below, and an average if its value ranged from 0.21 to 0.80 , and large if its value is greater than 0.80 .

\section{Discussion}

In this study, PowerPoint presentations' effect were examined for academic achievement of Social and National Studies in the fifth grade students at-risk for learning disabilities at primary schools. This indicates that the PowerPoint presentations helped the students at-risk for learning disabilities to understand the lessons of social and National studies recall the information and increase academic achievement in the experimental group. Also during the PowerPoint presentation, the chances of interactions with the students are high. The teacher consumes less time in delivering the same material when compared to traditional tool (blackboard and chalk). Therefore, the students have more time to interact with teacher. The data in Table 2 indicate that students exposed to self-instruction strategy achieved better in word recognition skills in all 
dimensions than those in control group. This supports the earlier findings by Acikalin, M.\& Duru,E. (2005) indicated that The integration of multimedia technologies in the social studies has made it possible for students to become more involved in their studies and create multimedia applications as part of their project requirements.

The results of Boon et al (2007), suggested that technology, as a component of the instructional process has been beneficial; improving and enhancing academic achievement, engagement, motivation, and study skills for both students with and without disabilities.

Therefore, there was a significant difference in The Social and National Studies Academic Achievement Test scores of students trained in PowerPoint Presentations than those that were not trained, students who trained in PowerPoint Presentations indicated that PowerPoint presentations increases interaction between them and their teacher, and preferred animation and sound congruent with the slide contents, Students also expressed a preference of dim the lights while giving lessons with PowerPoint presentations, students was more attentions and interested to have slides with pictures, and decorative background. The findings are also in line with that of Hyaty, (2007), indicated that the academic performance of experimental group is statistically significant in relation to control group; the designed program helped in increasing the students' academic performance, concentration. Photos, slides, and sound and movement effects can be added to the program. Alhabad, (2008) the study reached the following findings: Increase in the fourth year primary students' achievement, detention and positive attitudes towards using the PowerPoint Presentation in teaching geography. There was also a positive correlation between achievement in Geography and attitude towards using the computer. Aqikalin (2010) examine the use of exemplary social studies teachers' use of computer- supported instruction in the classroom. Case study methodological approach was used for this study. Four exemplary social studies teachers who use computer-supported instruction in their teaching practices were selected as participants. The data were collected from interviews and classroom observations. The data analysis indicated that all of the participants agreed that the computer is a powerful research tool, which facilitates students' work and makes the work faster and easier for the students. The participants used various types of computer-supported instruction in their classrooms. Al Othman, (2011), indicates that the expanded PowerPoint helped the students to understand the lecture and recall the information especially for poorly performing students.

The results of this study agree with related studies, which confirmed the use of PowerPoint Presentations to enhancing academic achievement of Social and National Studies. (Aqikalin, 2010; Alabad, 2008; Hyaty, 2007; Boon et al, 2007; Acikalin, \& Duru, 2005).

\section{Conclusion}

PowerPoint is extensively used in many sectors, but it is not so effectively propagated to academic sectors, especially to the primary schools in Saudi Arabia. This is a result of the need for hardware to run the technology, which currently does not exist in most of the classrooms of the primary Saudi Arabian school. Through this study, in one of the boys' primary Saudi Arabian school to examine how PowerPoint presentations can effectively enhance academic achievement in social and nation studies among students at-risk for learning disabilities. 
In light of the study results, given that PowerPoint presentations is very effective in enhance the academic achievement in social and nation studies among students at-risk for learning disabilities, it should be incorporated in the teacher education programs to prepare the prospective teachers, who may teach the low achieving students as well as the students with disabilities. The researcher recommended organizing training workshops for special and general education teachers on the application of PowerPoint presentations, and curriculum planners should plan the school and class activities to be more student-centered. This will help the students, especially those at-risk for learning disabilities, to achieve better academically. It will also help the students to develop confidence in their abilities to handle any learning task or problem they meet. Further extensive work can be carried out of PowerPoint presentations in primary schools for more subjects among students at-risk for learning disabilities.

\section{Appendix}

Some of slides from powerpoint presentions in fifth grade social and national studies
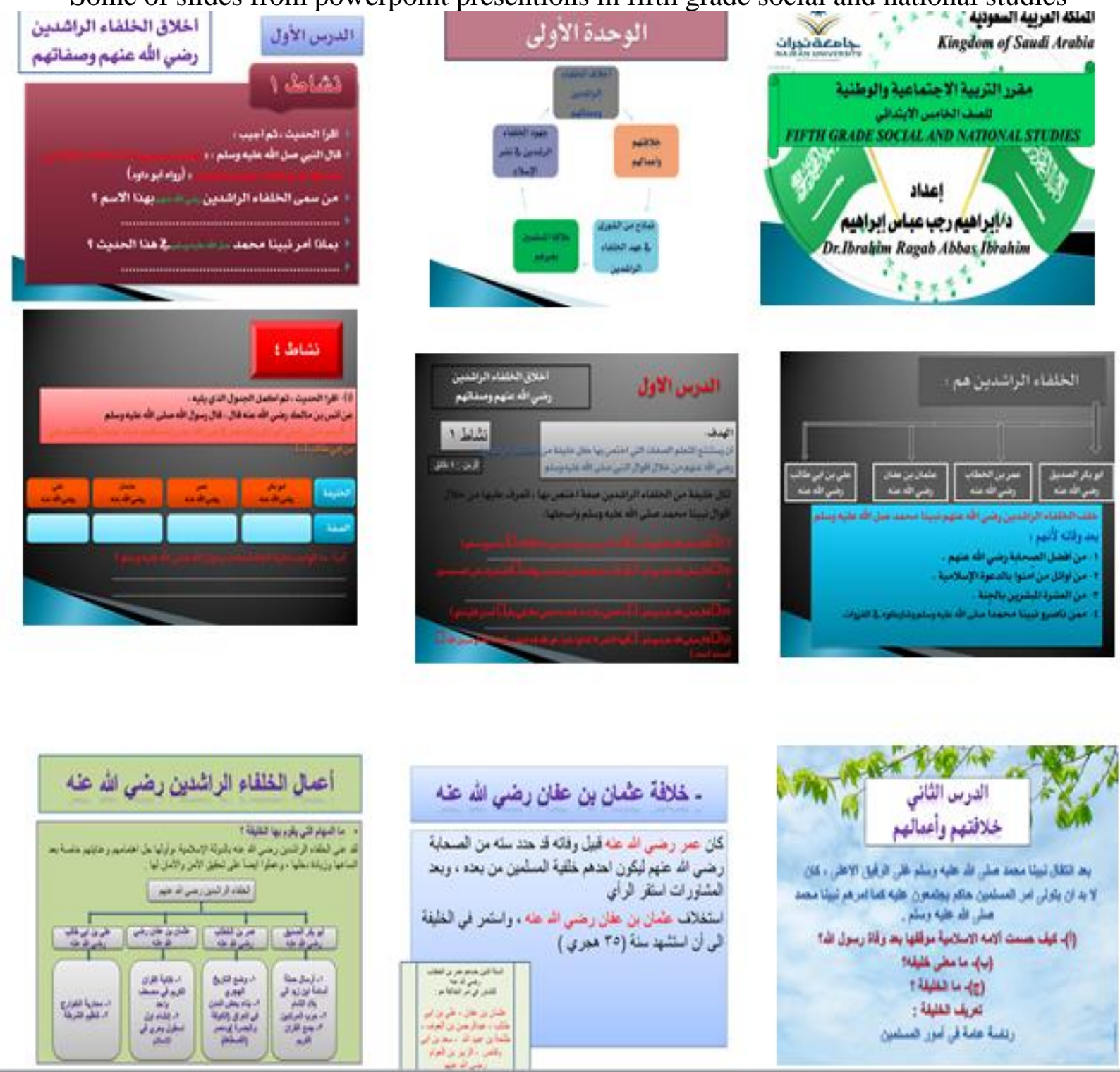

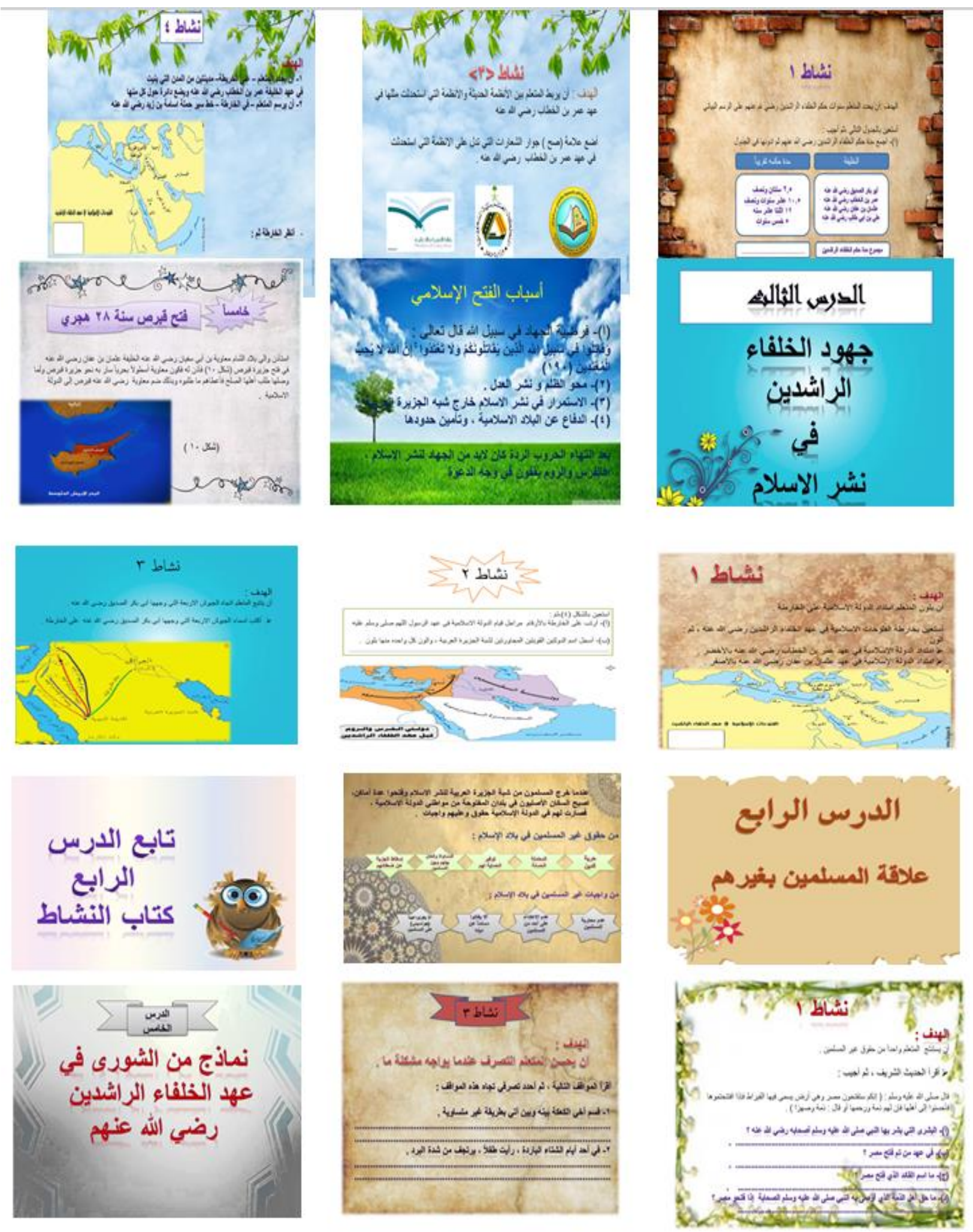

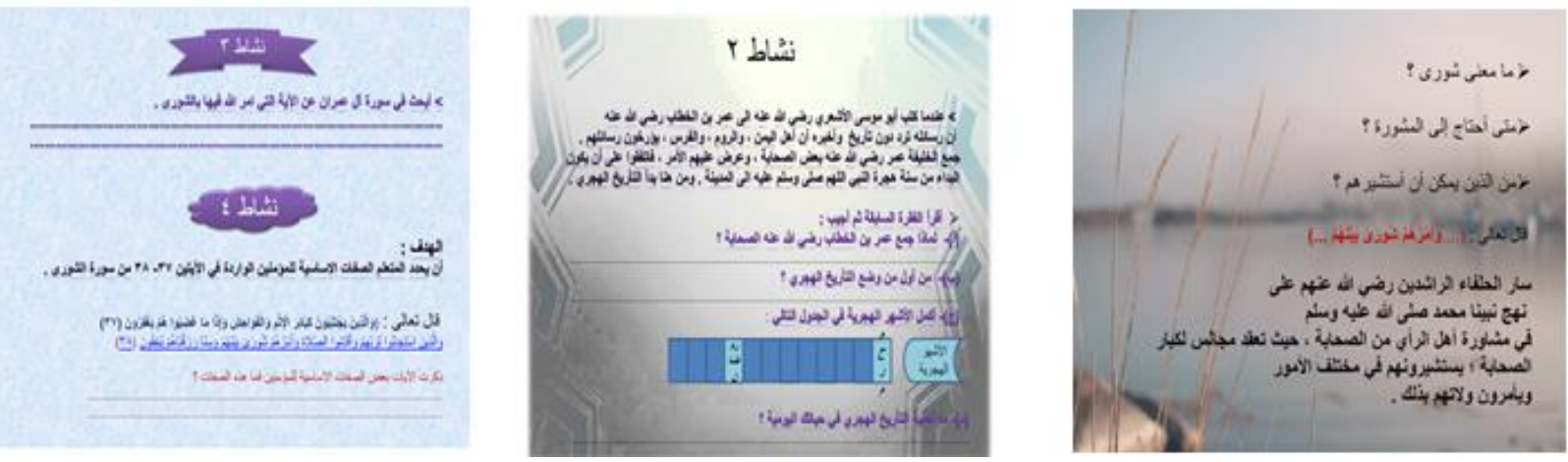

\section{References}

[1] Acikalin Mehmet, and Duru Erdinc. (2005)."THE USE OF COMPUTER TECHNOLOGIES IN THE SOCIAL STUDIES CLASSROOM." TOJET: The Turkish Online Journal of Educational Technology, 4: 2, 1303-6521.

[2] Acikalin Mehmet. (2010)."EXEMPLARY SOCIAL STUDIES TEACHERS USE OF COMPUTER-SUPPORTED INSTRUCTION IN THE CLASSROOM." TOJET: The Turkish Online Journal of Educational Technology, 9:4, 66-82.

[3] Al Ahmed Asma Mohammed. (2008)."THE EFFECT OF USING POWERPOINT PRESENTIONTATION ON ACADEMIC ACHIEVEMENT OF STUDENTS' SIXTH GRADE PRIMARY IN SCIENCE COURSE AT RIYADH CITY." (Unpublished master's thesis). King Saud University, Riyadh, Saudi Arabia.

[4] Al Neyadi Shafea Mohammed. (2009)."THE EFFECT OF INSTRUCTIONAL SOFTWARE IN THE ACHIEVEMENT OF FOURTH GRADERS IN ARABIC GRAMMAR IN AL AIN EDUCATIONAL DISTRICT."

http://www.edutrapedia.illaf.net/arabic/show_article.thtml?Id=295.

[5] Al Othman Manal Othman. (2011)."EFFECTIVENESS OF POWERPOINT PRESENTIONTATIONS IN SAUDI ARABIAN GIRLS' MIDDLE SCHOOL CLASSES." (Unpublished master's thesis). Edinburgh Napier University.

[6] Alhabad Fahad Bin- Faleh. (2008). "THE EFFECT OF USING POWER POINT PERSENTATION IN TEACHING GEOGRAPHY ON ACHIEVEMENT, RETENTION AND ATTITUDES TOWARDS USIN COMMPUTER OF FOURTH GEADE PRIMARY SCHOOL ROYS." The First Scientific Conference (Citizenship education and Curricula of Social Studies) Egypt.

[7] Balmeo Marilyni, Nimo Erika Mae, Pagal Aubrey, Puga Stephanie, ARISDAFQUINO. And Sanwen Jaleen. (2014)."INTEGRATING TECHNOLOGY IN TEACHING STUDENTS WITH SPECIAL LEARNING NEEDS IN THE SPED SCHOOLS IN BAGUIO CITY." The IAFOR Journal of Education, Vol II. II.

[8] Boon Richard, Cecil Fore, Blankenship Tracy and Chalk Jili. (2007). "TECHNOLOGY-BASED PRACTICES IN SOCIAL STUDIES INSTRUCTION FOR STUDENTS WITH HIGHINCIDENCE DISABILITIES: A REVIEW OF THE LITERATURE." Journal of Special Education Technology, 22, 4; 41-56.

[9] Cohen Jacob. (1988)."STATISTICAL POWER ANALYSIS FOR THE BEHAVIORAL SCIENCES." (2. Auflage), Hillsdale, N.J.:L. Erlbaum Associates.

[10] Coleman Mari Beth. (2009)."POWERPOINT IS NOT JUST FOR BUSINESSES PRESENTATIONS and COLLEGE LECTURES: USING POWERPOINT TO ENHANCE INSTRUCTION FOR STUDENTS WITH DISAABILITIES." Teaching Exceptional Children Plus Vol. 6, 1. 
[11] Hammond Linda Darling, Zielezinski Molly, and Goldman Shelley. (2014)."USING TECHNOLOGY TO SUPPORT AT-RISK STUDENTS' LEARNING." Alliance for Excellent Education I Stanford Center for Opportunity Policy in Education (SCOPE).

[12] Huitt William. (2011). "BLOOM ET AL.'S TAXONOMY OF THE COGNITIVE DOMIN." Educational Psychology Interactive. Valdosta, GA: Valdosta State University. Retrieved [date], from http://www.edpsycinteractive.org/topics/cogsys/bloom.html [pdf].

[13] Hyaty Omer Ahmed El Mostafa. (2007)."THE EFFECTS OF USING POWERPOINT PROGRAM ON THE ACADEMIC PERFORMANCE IN TOPOGRAPHICAL MAPS SYLLABUS FOR SECONDARY SCHOOLS IN SUDAN." Educational Studies-Sudan,16,8,82119.

[14] Jerome Annamaria. And Barbetta Patricia. (2005)."THE EFFECT OF ACTIVE STUDENT RESPONDING DURING COMPUTER-ASSISTED INSTRUCTION ON SOCIAL STUDIES LEARNING BY STUDENTS WITH LEARNING DISABILITIES." Journal of Special Education Technology, 20,3,13-23.

[15] Kanik Bou. (2013)."POWERPOINT AS A TEACHING TOOL: LECTURERS UNDERSTANDING AND PRACTICE AT THE CAMBODIA UNIVERSITY." (Unpublished master's thesis). The Royal University of Phnom Penh.

[16] Lari Fateme Samiel. (2014)."THE IMPACT OF USING POWERPOINT PRESENTIONTATIONS ON STUDENTS' LEARNING AND MOTIVATION IN SECONDARY SCHOOLS." Procedia - Social and Behavioral Sciences 98,1672 - 1677.

[17] Martorella Peter. (1997). "TECHNOLOGY AND THE SOCIAL STUDIES-OR: WHICH WAY TO THE SLEEPING GIANT." Theory \& Research in Social Education, 25:4, 511-514.

[18] Ministry of Education, the British, and Columbia School Superintendent's Association. (2011)."SUPPORTING STUDENTS WITH LEARNING DISABILITIES: A GUIDE FOR $\begin{array}{lllll}\text { TEACHERS." } & \text { Retrieved } & \text { August } & 10, & \end{array}$ http://www.bced.gov.bc.ca/specialed/docs/learning disabilities guide.pdf.

[19] Parette Howard, Blum Craig, Boeckmann NICHOLE, and Watts Emily. (2009). "TEACHING WORD RECOGNITION TO YOUNG CHILDREN WHO ARE AT RISK USING MICROSOFT® POWERPOINT TM COUPLED WITH DIRECT INSTRUCTION." Early Childhood Education. 36:393-401

[20] Steele Marcee, (2008). "TEACHING SOCIAL STUDIES TO MIDDLE SCHOOL STUDENTS WITH LEARNING PROBLEMS." Heldref Publications, 81, 5, 197-200. Szabo, Attila; Hastings, Nigel

[21] Szabo Attila, and Hastings Nigel. (2000)."USING IT IN THE UNDERGRADUATE CLASSROOM: SHOULD WE REPLACE THE BLACKBOARD WITH POWERPOINT?." Computers \& Education, 35, 175-187.

[22] Zhao Yah. (2007)."SOCIAL STUDIES TEACHERS' PERSPECTIVES OF TECHNOLOGY INTEGRATION." Jl. Of Technology and Teacher Education. 15(3), 202-333.

\footnotetext{
*Corresponding author.

E-mail address: hima_abbas2009@yahoo.com
} 